\title{
Três Idéias Sedutoras e Quatro Sugestões Preciosas: Algumas Reflexões de Jerome Kagan
}

Three seductive ideas and four precious suggestions: Some considerations by Jerome Kagan

José Fernando Bitencourt Lomônaco

Universidade de São Paulo 


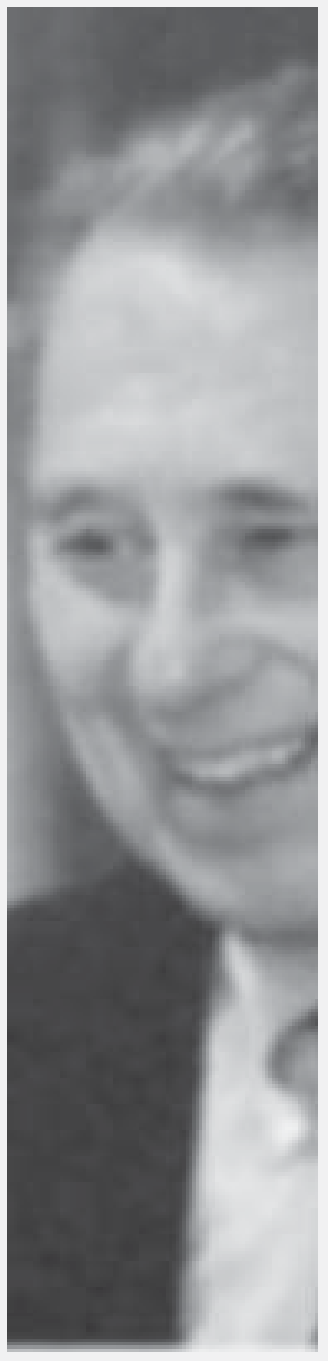

Resumo: São consideradas três idéias, denominadas por Jerome Kagan idéias sedutoras pela sua capacidade de se apresentarem como intuitivamente verdadeiras. A primeira é a de que processos psicológicos tais como inteligência, consciência, etc, podem ser amplamente generalizados para uma ampla gama de situações. A segunda refere-se ao determinismo infantil, à crença de que as primeiras experiências infantis constituem uma influência determinante no desenvolvimento. A terceira é relativa ao princípio do prazer, à noção de que o comportamento humano é regido fundamentalmente pela busca do prazer. Fundamentado em dados de diferentes áreas do conhecimento, Kagan demonstra a falácia de cada uma dessas idéias e apresenta quatro sugestões construtivas para aqueles que trabalham nas ciências sociais e comportamentais.

Palavras-chave: idéias falaciosas, generalização indevida, determinismo infantil, princípio do prazer.

Abstract: Three seductive ideas are considered, labeled by Kagan as such for their presentation as intuitively true. The first idea is that psychological processes named by terms as intelligence, consciousness, etc, can be generalized for a variety of situations. The second seductive idea is that of infant determinism, the notion that the first experiences are a determinant influence on the future development of the children. The third one is the pleasure principle, the notion that the human behavior is fundamentally oriented by the search of pleasure. Based on research data from a diversity of sciences, Kagan shows the fallaciousness of such ideas and gives four constructive suggestions for those who work in the social and behavioral sciences areas.

Key words: fallacious ideas, inappropriate generalization, infant determinism, pleasure principle.

Em 1998, o renomado psicólogo norteamericano Jerome Kagan, amplamente reconhecido por suas contribuições teóricas e empíricas ao estudo do processo de desenvolvimento humano, publicou um instigante livro denominado Three Seductive Ideas (Três Idéias Sedutoras), no qual faz uma séria crítica a três idéias amplamente disseminadas no domínio da Psicologia.

A leitura dessa obra convenceu-me da importância de partilhar, com a comunidade psicológica brasileira, as sugestivas idéias desse autor, uma vez que muitos de nós possivelmente estamos também seduzidos por essas idéias e, o que é muito pior, elas seduzem nossos alunos e contribuem, dessa maneira, para perpetuá-las. Assim sendo, decidi escrever este artigo a fim de divulgar o conteúdo do livro em apreço.

Há dezenas de anos, Jerome Kagan vem se dedicando ao estudo teórico e à investigação empírica em Psicologia do desenvolvimento, tendo publicado vários livros e um respeitável número de artigos em periódicos científicos. Em seu trabalho de pesquisa, tem-se voltado para o estudo do desenvolvimento cognitivo 


\section{A primeira idéia falaciosa, analisada no capítulo denominado $A$ paixão pela abstração, é a crença de que a maioria dos processos psicológicos se generaliza amplamente.}

e emocional de crianças, com especial interesse pela investigação do temperamento e das emoções morais. Atualmente é professor de Psicologia na Universidade de Harvard e co-diretor do Mind-Brain Behavior Iniative, nessa mesma universidade. Em face de sua vida acadêmica, inteiramente dedicada ao estudo, pesquisa e divulgação da Psicologia, especialmente à Psicologia do desenvolvimento, acredito eu que ele tenha méritos suficientes para ter suas idéias amplamente divulgadas e submetidas ao escrutínio de profissionais e estudantes de Psicologia brasileiros.

Antes, todavia, gostaria de salientar que, ao apresentá-las, certamente não estarei fazendo inteira justiça ao pensamento de Jerome Kagan, dado que, ao procurar resumir ou sintetizar suas idéias, estarei deixando de lado, por uma questão de espaço, muitos dados e argumentos constantes do trabalho. Recomenda-se, pois, aos mais interessados, consultar a obra original.

Um outro aspecto que gostaria de considerar é que, embora o objetivo principal deste trabalho seja o de divulgar as idéias de Kagan entre a comunidade psicológica e o de despertar o interesse do leitor pela leitura do original, não me furtarei a tecer algumas considerações e fazer uma análise crítica, ainda que não exaustiva, do texto em tela.

No ano seguinte ao da publicação do texto de Kagan nos Estados Unidos, Frank C. Keil, professor do Departamento de Psicologia de Yale e conceituado estudioso do desenvolvimento cognitivo, publicou uma primorosa resenha do livro no Contemporary Psychology (1999), na qual, ao mesmo tempo em que descreve o conteúdo do texto, apresenta algumas críticas às afirmações de Kagan.

Neste trabalho, após a exposição de cada uma das idéias sedutoras, apresentarei algumas de tais críticas juntamente a minhas reflexões pessoais. Esse contraponto não visa, de forma alguma, a desacreditar ou desmerecer as idéias de Kagan, mas tão somente a enriquecer a compreensão do texto, apontando algumas limitações que, sem comprometer a essência das argumentações do autor, permitem, no meu entendimento, contextualizar melhor tais idéias e enriquecer o debate sobre seu poder de sedução.

Vamos, pois, conhecer as três idéias falaciosas que, segundo Kagan, ao longo da história da Psicologia, vem dificultando melhor compreensão de processos e fenômenos psicológicos e levando a uma série de interpretações e/ou conclusões equivocadas em face de seu poder de sedução.

A primeira idéia falaciosa, analisada no capítulo denominado A paixão pela abstração, é a crença de que a maioria dos processos psicológicos se generaliza amplamente. Como uma conseqüência de tal crença, muitos estudiosos acreditam que não é fundamentalmente importante especificar o agente que está sendo estudado (homem ou animal), o contexto no qual o sujeito atua (laboratório, ambiente natural, local de trabalho), uma vez que se acredita que conclusões amplas podem ser retiradas, não obstante o agente e o contexto. Por exemplo, uma qualidade denominada inteligência é aplicada a animais, crianças, estudantes universitários e programas de computador. Os dados utilizados para inferir essa qualidade incluem ratos percorrendo labirintos, a sobrevivência das espécies, crianças olhando fixamente para figuras novas, a posse de um grande vocabulário, tempos de decisão rápidos, a capacidade de recordar uma longa fileira de números e a correta aplicação de regras lógicas. Nas palavras de Kagan (1998): “A noção de que um único processo mental pode mediar um conjunto tão diverso de fenômenos vai muito além dos limites da imaginação da mente mais aberta" (p. 2). 
Kagan afirma que a preferência por não especificar um evento e, em conseqüência, supergeneralizá-lo, está provavelmente enraizada na natureza biológica da mente humana e é um dos fenômenos mais bem estabelecidos nos laboratórios psicológicos. $\mathrm{O}$ cérebro humano, da mesma maneira que o cérebro dos animais, está preparado inicialmente para atentar para a generalidade, e não para a particularidade. É a experiência que nos ensina a refinar nossa percepção inicial.

Pode-se afirmar que esse refinamento da observação constitui um dos propósitos fundamentais das ciências empíricas, pois é através desse processo de análise de conceitos mais gerais e sua substituição por famílias de conceitos mais específicos, distintos, porém relacionados, que a ciência tem caminhado rumo a melhor compreensão da natureza.

A aplicação desse refinamento de conceitos aos processos cognitivos é algo mais recente em Psicologia. Por exemplo, a capacidade de memória, que os psicólogos de alguns anos atrás consideravam uma capacidade unitária, é agora amplamente reconhecida como um conjunto de processos distintos mediados por diferentes circuitos cerebrais. Todavia, como assinala Kagan (1998):

Apesar dessas poucas vitórias, demasiados cientistas sociais e comportamentais retêm uma profunda afeição por conceitos amplos como aprendizagem, medo, depressão, comunicação, amor e consciência, acreditando que cada termo descreva fielmente um agrupamento coerente na natureza (p.3).

A segunda idéia sedutora é o determinismo infantil, ou seja, a idéia de que as primeiras experiências das crianças até aproximadamente dois anos de idade são determinantes para a formação de traços da personalidade adulta. A palavra crucial, na afirmação anterior, é o termo determinante, pois o que se critica não é a afirmação que os eventos dos dois ou três primeiros anos influenciem a formação da personalidade, mas que a determinam de maneira definitiva, ou, em outras palavras, para grande parte dos psicólogos, parece razoável supor que as primeiras estruturas mentais criadas pela experiência são preservadas indefinidamente, como a marca de uma dobradura num papel.

Segundo Kagan (1998), existem três boas razões para acreditar na preservação dessas primeiras estruturas. São elas: 1a) o determinismo infantil transmite a ilusão de ser mecanicista, ou seja, é mais fácil para nós afirmar uma relação de causa e efeito se cada nova qualidade é precedida por alguma outra que traz uma substancial contribuição a ela do que se um novo comportamento emerge subitamente devido a eventos traumáticos ou mudanças maturacionais no cérebro; 2aํ) tal crença torna proveitosa e significativa a ação dos pais, isto é, se não for possível aos pais inculcar atitudes, valores e comportamentos senão no final da infância, então suas ações, nesses dois ou três primeiros anos de vida, parecerão inúteis e desprovidas de sentido, e $3^{a}$ ) talvez a mais forte delas, essa crença está de acordo com a doutrina do igualitarismo. Kagan afirma que cada período histórico é dominado por uma visão filosófica que a maioria dos cientistas e estudiosos evita contrariar. Em nossos tempos, vigora a ética do igualitarismo, que afirma a igualdade de direitos e oportunidades para todos os seres humanos. Nas palavras do autor:

Se a sociedade puder dispor de experiências estimuladoras do crescimento para todas as crianças e se os produtos psicológicos resultantes forem preservados apesar das vicissitudes da vida posterior, nós poderemos aproximar-nos do ideal de uma sociedade de iguais. Mas se, por outro lado, as frustrações da pobreza ou do preconceito puderem produzir descontinuidades psicológicas na 
adolescência, apesar de uma infância benevolente, a premissa do igualitarismo ficaria ameaçada. Assim, o sentimento comunitário que cerca a idéia de igualdade mantém essa suposição (p.5).

Um outro aspecto que contribui para a permanência da crença no determinismo infantil é a ambigüidade do fenômeno que se deseja explicar. E isso porque as qualidades supostamente determinadas pelas experiências infantis - tais como bom ajustamento, auto-realização, caráter, personalidade saudável, etc - são tão gerais que, com elas, não temos condições de refutar

Comolembra Kagan (1998), os biólogos, ao contrário, geralmente começam com resultados observóveis e, então, tentam explicá-los. (ou confirmar) a noção de que as primeiras experiências são as responsáveis por tais resultados. Na medida em que os adeptos do determinismo infantil forem incapazes de especificar um resultado particular para uma determinada classe de experiências infantis p. ex., fobia de animais, introversão, suicídio, abuso de drogas ou pobre realização escolar - eles tornam muito difícil o teste da hipótese.

Como lembra Kagan (1998), os biólogos, ao contrário, geralmente começam com resultados observáveis e, então, tentam explicá-los. A proporção de ervilhas lisas e rugosas no herbarium de Mendel despertou a idéia de genes como causa da hereditariedade. Vinho estragado foi o fato que levou Pasteur a postular a existência de micróbios. Observase nesses exemplos, e em muitos outros que poderiam ser facilmente lembrados, que os fatos vêm antes dos conceitos explicativos. Muitos estudantes do desenvolvimento, ao contrário, invertem essa seqüência, postulando causas - como o brincar com uma criança ou ouvir música clássica na infância antes que eles especifiquem o que desejam explicar. Kagan nos previne que:

Nenhum investigador sério do desenvolvimento humano desafia a afirmação que as experiências sociais dos primeiros dois anos esculpem em algum grau o perfil que nós vemos no segundo aniversário da criança. Crianças que são negligenciadas são obviamente menos alertas, menos verbais e menos entusiastas do que aquelas que recebem cuidados previsíveis, afeição e contatos divertidos. Todavia, o perfil observado na idade de dez anos é o resultado de uma década de experiências, não apenas do que ocorreu nos primeiros dois anos (p.6).

A terceira idéia sedutora, porém falaciosa, muito popular entre psicólogos e economistas, é a de que a maioria das ações humanas é motivada pela busca do prazer sensorial. Tal concepção contrapõe-se à da grande maioria dos sistemas filosóficos que atribuem o poder maior de dirigir as ações humanas a um motivo diferente, qual seja, o de considerar o self ou a si mesmo como possuidor de boas qualidades. Segundo Kagan (1998), os filósofos têm escrito muito mais sobre a moral do que sobre quaisquer outras qualidades porque essa é uma característica singular e distintiva de nossa espécie.

Em resumo, em seu estudo, Kagan (1998) conclui que 1) muitos processos psicológicos não são amplamente generalizáveis; 2) que a maioria das características do adulto não são determinadas pelas experiências dos dois primeiros anos e 3) que a maioria de nossas decisões diárias são tomadas buscando obter ou manter um sentimento de virtude. Vejamos, agora, mais detalhadamente, como o autor analisa cada uma dessas questões.

\section{A paixão pela abstração}

A idéia matriz desse capítulo é a tendência do ser humano de buscar conceitos extremamente amplos e gerais, capazes de explicar um número cada vez maior de fenômenos. Embora tal desejo possa ser perfeitamente justificado dentro das ciências, que buscam, idealmente, com poucos conceitos, abranger a totalidade de fenômenos de sua área de conhecimento, o resultado nem sempre se 
ajusta a essa expectativa, mormente nas ciências humanas. É isso que Kagan procura transmitir nesse capítulo, no qual examina conceitos psicológicos bastante populares que, no seu entender, ilustram o fenômeno da supergeneralização ambiciosa e indevida, entre eles, o medo, a consciência, a inteligência e o temperamento, cada um deles representando um conjunto diverso de fenômenos que seriam mais bem explicados por uma família de termos diferentes, ainda que relacionados. Devido às limitações de espaço, apenas um desses termos será aqui considerado - o de inteligência - a fim de ilustrar as idéias do autor a respeito dessa idéia falaciosa.

O primeiro teste de inteligência, criado por Binet e Simon em 1905, não tinha outra ambição senão a de prever o desempenho escolar de uma criança. Seus autores não elaboraram complexos argumentos teóricos a respeito do significado da inteligência. Todavia, posteriormente, outros cientistas se preocuparam com o significado e as origens do fenômeno que estava sendo medido pelos testes de inteligência. Duas figuras muito importantes nesse mister foram Charles Spearman e L. L. Thurstone, cujo trabalho data de 75 anos atrás. É bem conhecida a discussão entre esses dois autores a respeito da natureza da inteligência: Spearman, que afirma a existência de uma capacidade unitária, o fator g, e Thurstone, que postula a ocorrência de sete diferentes capacidades cognitivas: análise perceptiva, capacidade numérica, capacidade verbal, capacidade espacial, memória, indução e raciocínio dedutivo. Segundo Kagan (1998), apesar da racionalidade dos argumentos de Thurstone, suas idéias nunca suplantaram a noção mais simples de g. O autor passa, então, a se perguntar porque a palavra inteligência, entendida como um fator geral, é tão difícil de ser eliminada de nosso vocabulário.

Uma primeira resposta reside na crença de que a inteligência é algo herdado, uma capacidade com a qual o indivíduo já nasce. Atrás de tal crença, existe uma respeitável quantidade de estudos, mormente os realizados com gêmeos idênticos, fraternos e irmãos comuns, demonstrando que, quanto mais similares forem os sujeitos em termos de sua dotação genética, menores as diferenças no quociente intelectual, ainda que seu ambiente de criação seja bastante diferente.

Kagan questiona, todavia, a dificuldade em avaliar a natureza exata da contribuição biológica para os escores dos testes de inteligência. A esse propósito, recorre a uma citação do psicólogo John Carroll, em que este afirma textualmente:

Eu sempre pensei que seria difícil avaliar as influências genéticas sobre os escores de testes que são tão patentemente funções de experiências de aprendizagem específicas como os típicos testes de QI... Dada a dificuldade de controlar ambientes, provavelmente será muito difícil proporcionar evidência convincente para as influências genéticas, mesmo em estudos de gêmeos e de famílias (p. 54).

A seguir, apresenta vários estudos cujos resultados, segundo ele, questionam fortemente a existência de g. A título de ilustração, um desses estudos será considerado. O estudo avaliou o desempenho de crianças no início da escolaridade, filhas de pais pobres e pouco instruídos, e às quais se costuma atribuir baixos escores de QI, numa tarefa de leitura de fileira de palavras. As crianças foram solicitadas a ler tais palavras o mais rapidamente possível. O desempenho dos sujeitos ficou abaixo da média das crianças de classe média. Interpretou-se tal resultado como o reflexo de um déficit geral no processamento de informações de forma automática e eficiente. Todavia, uma réplica desse estudo feito com crianças em Boston e na Índia revelou, surpreendentemente, que a 
maioria dessas crianças era capaz de ler fileiras de cores e de figuras de objetos familiares tão rapidamente quanto as crianças que eram excelentes leitoras. A lentidão na leitura ocorria apenas quando elas estavam lendo letras, ou seja, essas crianças não tinham um déficit intelectual geral; ao invés disso, era a falta de familiaridade com as letras que as impedia de lê-las rapidamente.

Um outro fato contrário à generalidade da inteligência são os baixos índices de correlação que se obtém quando são correlacionados os resultados dos vários subtestes de um teste de inteligência. A escala de inteligência Wechsler para crianças, um dos mais populares testes de inteligência, avalia um pequeno número de habilidades mentais, incluindo vocabulário, memória de curto prazo para números, capacidade de fazer inferências a partir de figuras e talento para solucionar quebra-cabeças. Se a inteligência fosse uma capacidade unitária, as correlações entre os escores desses quatro testes deveriam ser altas, mas elas são modestas, por volta de 0,40 . Esse fato é inconsistente com a noção de que a inteligência seja uma característica unitária.

Kagan, então, refere-se aos grandes progressos alcançados no estudo da memória humana quando a fé numa qualidade unitária foi abandonada. Segundo ele, até aproximadamente 1970, a memória humana era considerada uma capacidade unitária. A memória das pessoas era classificada como boa, regular ou ruim, independentemente do conteúdo a ser recordado. Atualmente sabese que a memória não é uma capacidade única, mas um conjunto de processos psicológicos distintos. Um desses processos diz respeito à recordação consciente de fatos - a capital do Brasil, os afluentes do Amazonas, a localização de uma rua, os nomes de nossos parentes, etc - e é chamada de memória declarativa. Esta, por sua vez, pode ser dividida em processos de memória relacionados à recordação de fatos ou eventos isolados - a memória semântica - e a recordação consciente do lugar e/ou do tempo em que um fato foi aprendido ou um evento ocorreu - a memória episódica. Os circuitos neurais que medeiam a memória semântica e episódica são diferentes. Adultos com lesão no hipocampo têm a memória episódica seriamente prejudicada, mas podem recordar a linguagem, têm desempenho adequado na escola e recuperam lembranças armazenadas.

Uma segunda forma de memória é a capacidade para recordar-se de procedimentos, a memória sobre como fazer, sobre como, p.ex., andar de bicicleta, dar um nó na gravata ou executar uma seqüência de movimentos de dança. É a chamada memória de procedimentos.

Um terceiro tipo é a memória implícita. Se mostrarmos a crianças de oito anos uma série de fotos de crianças com quem elas brincavam quatro anos antes, elas provavelmente não reconhecerão seus antigos colegas - sua memória declarativa é ruim. Todavia, se a condutibilidade elétrica da pele for medida, tais crianças apresentarão mais suor diante das fotos de crianças com as quais brincaram anos antes do que de fotos de crianças completamente desconhecidas.

Finalmente, cabe distinguir entre memória de curto prazo e de longo prazo. Na memória de curto prazo, o indivíduo deve recordar-se da informação por um breve intervalo de tempo, apenas alguns poucos segundos. É o tipo de memória envolvida quando necessitamos saber um número de telefone. Já a memória de longo prazo refere-se à recuperação de informação obtida num passado distante. Pessoas amnésicas têm a memória de curto prazo seriamente prejudicada, embora possam recordar-se bem de fatos ocorridos muitos anos antes. 
Dado esse conjunto de descobertas dos últimos vinte e cinco anos, nenhum psicólogo contemporâneo diria simplesmente que uma pessoa tem uma boa memória sem especificar se ele está se referindo à memória declarativa, de procedimentos ou implícita, à memória de curto ou longo prazo e às formas de informação recordada: palavras, números, cenas, melodias ou pesadelos. Deve ser notado, nesse contexto, que os testes de inteligência padronizados medem apenas a memória semântica declarativa para fatos, deixando de lado as memórias episódica, implícita e de procedimentos.

Finalmente, Jerome Kagan se pergunta porque a noção do fator g, com todas as limitações que ela acarreta para explicar o comportamento dito inteligente, foi e é ainda tão popular dentro da Psicologia. Sua explicação é, no mínimo, curiosa. Segundo ele, quando uma ciência é jovem - e a Psicologia é uma das mais jovens - seus praticantes são vulneráveis a uma forma de pensar que a mente acha atraente, embora não se ajuste muito bem aos fatos da natureza, qual seja, existe, por parte dos adeptos, uma forte preferência por idéias que impliquem essências estáveis, possuem simetria e são simples. A noção de g, ou inteligência geral, preenche os três requisitos.

Parece intuitivamente verdadeiro que o mundo seja constituído de arranjos únicos de elementos estáveis, que são as essências dos objetos. Não obstante tenhamos muitos exemplos de madeira queimada que se transforma em cinzas, da carne que se decompõe com o tempo, de folhas verdes que se tornam amareladas e apodrecem no solo, de homens, animais e plantas que nascem, crescem e morrem, continuamos a acreditar que, sob a superfície mutável e aparente das coisas do mundo, uma camada invisível de formas imutáveis permanece. Essa idéia é chamada de essencialismo. O conceito de g é tratado como uma essência que permanece subjacente a toda forma de comportamento inteligente.

A idéia de inteligência geral também preenche o critério de simetria. A simetria, na verdade, não é muito comum na experiência diária. Veja-se, por exemplo, o arranjo das nuvens no céu, das árvores numa floresta, de vacas num pasto, de estrelas no céu ou de casas numa rua. Não obstante, quando se apresenta a distribuição simétrica de escores de QI, com média de 100 e números aproximadamente iguais acima e abaixo desse valor arbitrário, a simetria da curva normal parece persuadir-nos de sua verdade. Nas palavras de Kagan (1998): "A noção de uma qualidade humana que é simetricamente distribuída entre todas as pessoas do mundo gerou a intuição de que os cientistas finalmente detectaram uma das intenções de Deus" (p.68).

Finalmente, a idéia de inteligência geral é simplicidade pura. O número de talentos cognitivos humanos é provavelmente tão numeroso quanto o das doenças às quais $\mathrm{o}$ homem é vulnerável. Ele inclui os diferentes processos de memória, a intuição, a formação de conceitos, a solução de problemas, a criatividade, o pensamento indutivo e dedutivo, a avaliação, a aquisição de novos comportamentos e de novos conhecimentos e muitos, muitos outros. Não obstante, toda essa extraordinária diversidade é ignorada quando declaramos nossa lealdade ao fator $\mathrm{g}$.

Os biólogos de há muito são menos tolos. Eles não sugerem que os seres humanos diferem geneticamente numa qualidade denominada "saúde geral" e que as pessoas herdam uma vulnerabilidade alta, média ou pequena a todas as doenças. Os efeitos genéticos sobre as funções vitais são extremamente específicos na maior parte das vezes. Não obstante, alguns psicólogos se recusam a abandonar a idéia de que cada indivíduo herda uma qualidade que determinará se ele possui um grau de inteligência alto, moderado ou baixo.
Os biólogos de há muito são menos tolos. Eles não sugerem que os seres humanos diferem geneticamente numa qualidade denominada "saúde geral"e que as pessoas herdam uma vulnerabilidade alta, média ou pequena a todas as doenças. 
Em face das considerações precedentes, conclui Kagan:

Os indivíduos diferem em seu desempenho nos testes cognitivos e na fisiologia cerebral. Seria extremamente importante se a causa dessas diferenças fosse um conjunto particular de genes que torna algumas pessoas mais competentes em todos os testes. Como isso é improvável, o conceito de g não se refere a um fenômeno natural, e, como o éter de Newton, está atrasando o progresso teórico (p. 69).

\section{Comentários}

Neste capítulo, é chamada a atenção para o erro de fazer afirmações demasiadamente gerais que não levam em conta o contexto no qual ocorre o fenômeno estudado. Todavia, como sugere Keil (1999) na citada resenha, tão perigoso quanto fazer afirmações excessivamente amplas e imprecisas é o perigo de "... inundar as revistas científicas com minúsculas observações dependentes do contexto, estabelecidas de maneira tal a não ter nenhuma generalidade..." (p. 548). Ou, em outras palavras, a crítica ao emprego de termos extremamente amplos não deve levar ao seu oposto, qual seja, considerar únicos toda situação e todo comportamento. Tal atitude, levada ao extremo, inviabilizaria a existência da Psicologia como ciência, pois, como há muitos séculos nos ensinou Aristóteles, não se faz ciência do particular.

Um outro aspecto lembrado por Keil, embora não inviabilize a idéia de Kagan, ajuda-nos a entender a origem dessa "paixão pela abstração" no ser humano. Trata-se da tendência de igualar os estados cerebrais com estados mentais, de supor que estados biológicos e processos mentais de alguma forma conferem um status unificador aos comportamentos que são mais intimamente associados a eles. Por exemplo, se você observa uma situação de esquiva em ratos e seres humanos, você pode ver pouca coisa em comum, porém, se você sabe que estão ocorrendo padrões biológicos similares em ambas as situações, os estados de medo e ansiedade presentes nesses contextos tão díspares passam a ser vistos como muito mais semelhantes. Como salienta Keil (1999), “... se regiões análogas do cérebro estão ativas em duas espécies diversas em situações superficialmente semelhantes, semelhanças muito mais profundas são agora atribuídas às duas espécies" (p. 548). Dessa forma, muito embora as advertências de Kagan sejam extremamente pertinentes, resta saber não só porque tais idéias têm tal apelo, não só entre leigos quanto entre especialistas, mas também identificar algum mérito que elas eventualmente possam ter.

Uma das questões mais importantes na Psicologia atual, no meu entender, é não aceitar cegamente todo correlato biológico como a explicação final do comportamento, mas também não rejeitar indiscriminadamente todos os laços entre a Biologia e o comportamento. No momento em que os psicólogos parecem ainda continuar polarizando a velha questão natureza versus ambiente, as ponderações de Kagan sobre como um nível de análise pode informar problemas de outros níveis são realmente bem-vindas.

\section{A fascinação do determinismo infantil}

A segunda idéia sedutora é tratada no capítulo denominado $A$ fascinação do determinismo infantil. Kagan começa esse capítulo com a seguinte indagação: "Quão para frente pode o passado remoto estender suas mãos?" E ele responde com o exemplo da Física, quando afirma que a temperatura do Universo aproximadamente três graus Kelvin - resultou certamente da dissipação da intensa radiação criada pelo Big Bang. Nenhuma outra ciência, diz o autor, tem tanta confiança no poder 
explicativo de um evento inicial ocorrido num passado remotíssimo.

Todas as sociedades especulam a respeito das causas da variação entre seus membros. As sociedades ocidentais decidiram que as experiências que ocorrem nos primeiros anos de vida são as forças mais potentes na determinação do tipo de pessoa que a criança virá a ser.

Segundo Kagan (1998, p.86),

A aceitação relativamente não crítica dessas suposições requer uma profunda fé numa conexão inquebrantável entre o passado e o presente e uma visão de cada vida com uma auto-estrada que liga o primeiro ao último dia. Essa visão do desenvolvimento repousa sobre a suposição de que toda experiência produz uma mudança física permanente em algum lugar do sistema nervoso central e, em conseqüência, as primeiras experiências proporcionam os andaimes para o futuro pensamento e comportamento da criança. O desenvolvimento é análogo à construção de uma casa: assim como a forma e a qualidade das fundações determinam o resultado subseqüente, as primeiras experiências têm uma esmagadora prioridade na determinação da forma e da qualidade da vida mental e emocional do adulto. A fita virgem, uma metáfora para o cérebro infantil, é permanentemente alterada depois de cada experiência, e essas mensagens são preservadas com fidelidade por um período indefinido.

A fé nessa conexão entre o passado e o futuro tem sido associada à crença em períodos críticos no desenvolvimento. Esse conceito, popular há uns cinqüenta anos, perdeu um pouco de seu apelo, mas começou a retornar à Psicologia nos últimos anos. A idéia de períodos críticos é particularmente bem definida em algumas espécies animais. A estampagem de patinhos e gansos é um excelente exemplo. Apenas algumas horas após o nascimento, esses animais seguirão o primeiro objeto em movimento que vêem, geralmente a mãe. Estudos em laboratório demonstraram que, na ausência da mãe, a estampagem pode ocorrer com pessoas ou objetos em movimento. Portanto, durante um curto intervalo de tempo, denominado período crítico, certas experiências podem afetar permanentemente o comportamento futuro dos animais.

Dois neurocientistas, David Hubel e Torsten Wiesel, descobriram, no desenvolvimento da visão, outro exemplo dramático de período crítico. Esses investigadores verificaram que, se o olho de um gatinho recém-nascido fosse tapado no período entre o $14^{\circ}$ e e o $30^{\circ} \mathrm{dia}$, de forma tal que apenas um lado do córtex visual recebesse estimulação visual, o animal ficaria permanentemente cego desse olho. Todavia, se esse mesmo olho fosse fechado um mês após o nascimento, nenhuma mudança ocorreria no cérebro, e a visão do animal seria normal após a retirada do tampão no olho.

A noção de período crítico estimulou a imaginação de muitos psicólogos do desenvolvimento, que supuseram que deveria haver também períodos críticos no desenvolvimento humano. Em 1976, Marshal Klaus e John Kennell afirmavam que a ligação da mãe com a criança deve ocorrer nas primeiras horas após o nascimento, a fim de que o desenvolvimento ocorra normalmente.

Entretanto, tem sido difícil identificar períodos críticos no desenvolvimento humano que sejam tão convincentes quanto as descobertas com patos, gansos e gatinhos. Kagan cita vários estudos que investigaram o desenvolvimento de crianças criadas em orfanatos nos primeiros anos de vida e posteriormente adotadas por famílias que as educaram. Em todos os estudos considerados, as crianças apresentaram nítidas melhoras nos vários aspectos avaliados, indicando que a privação dos primeiros anos
"O

desenvolvimento é análogo à construção de uma casa: assim como a forma e a qualidade das fundações determinamo resultado subseqüente, as primeiras experiências têm uma esmagadora prioridade na determinação da forma e da qualidade da vida mentale emocional do adulto".

Kagan 
não comprometeu irremediavelmente o seu desenvolvimento.

Uma vez que, como visto, a doutrina do desenvolvimento infantil acaba por ignorar as muitas e poderosas influências que afetam o perfil de adolescentes e adultos jovens após o segundo ano, Kagan passa a considerar alguns fatores que, no seu entendimento, exercem poderosa influência no desenvolvimento humano. São eles: a ordem de nascimento, a identificação com a classe social ou grupo étnico e o período histórico.

No tocante à ordem de nascimento, o autor afirma, fundamentado em vários estudos, que a posição da criança na família, especialmente se a diferença de idade entre os irmãos for de menos de quatro anos, afeta um certo número de qualidades psicológicas. Uma dessas qualidades é a atitude perante uma autoridade legítima. Os primogênitos geralmente mostram uma atitude mais respeitosa diante da autoridade, enquanto os mais novos são mais céticos e desrespeitosos, ou seja, o irmão mais velho numa família está mais disposto a adotar os valores paternos.

As diferentes experiências vividas pelos irmãos mais velhos e mais novos ajudam a explicar porque, para os mais novos, é um pouco mais fácil resistir às pressões sociais para conformarse às expectativas de pais, professores e outros adultos. Considere-se um hipotético exemplo de duas crianças da classe média, criadas por pais afetuosos e justos. A concepção inicial da autoridade adulta está baseada na categorização dos pais que, para o primogênito, parece possuir características desejáveis, especialmente o poder de comandar e dirigir. Se os pais elogiam a conformidade a seus valores e punem os desvios, será difícil para o mais velho escapar desses imperativos e rejeitar os valores de civilidade e realização.

Não ocorre exatamente o mesmo com o irmão mais novo, que vive num mundo diferente.
Embora o irmão mais velho seja percebido como uma autoridade menor, ele é muito menos carinhoso e compreensivo que os pais. Ele caçoa do mais novo, pega seus brinquedos e está sempre lembrando a ele sua relativa impotência, quem é o mais forte dos dois. Esses eventos diários acabam por alterar a concepção dos mais novos a respeito daqueles que são mais velhos e, freqüentemente, geram ressentimentos em relação às pessoas dotadas de autoridade.

Kagan ilustra a sua argumentação citando um interessante estudo de Frank Sulloway, publicado em 1996, a respeito da atitude de cientistas primogênitos ou irmãos mais novos quando do surgimento de concepções teóricas radicalmente novas. Por exemplo, a maioria dos naturalistas que fizeram comentários sobre a teoria da evolução, entre 1860 e 1875, rejeitando as idéias revolucionárias de Darwin, eram primogênitos. Entre os mais novos, sua aceitação foi três vezes maior. Na verdade, tanto Charles Darwin quanto Alfred Russel Wallace, co-autor da teoria da evolução, eram irmãos mais novos.

Num outro estudo em que foram avaliadas vinte e oito diferentes idéias científicas inovadoras, verificou-se que o número dos que apoiaram esses novos avanços na ciência era duas vezes maior entre os irmãos mais novos do que entre os irmãos mais velhos.

A conclusão de Kagan, a partir de dados como esses, é a de que as conseqüências da ordem de nascimento são relevantes para o debate a respeito da conexão entre as primeiras experiências e a formação de qualidades psicológicas no adulto, uma vez que as diferentes construções dos irmãos mais novos e mais velhos estão ausentes nos primeiros anos de vida. Em suas palavras (p.113):

A imaturidade cognitiva da criança de dois anos impede-a de inferir que ela é menos adequada do que seu irmão mais velho. As importantes 
conseqüências psicológicas da ordem de nascimento devem esperar até que as crianças possam apreciar sua relação com um irmão e meditar a respeito da diferença das atitudes parentais em relação a cada membro da família.

A seguir, o autor discorre sobre a importância da identificação com a classe social ou com o grupo étnico. Tal importância, segundo ele, está alicerçada em três observações:

- que os valores éticos mantidos pela maioria dos adolescentes são mais similares aos de seus pais e de outros adultos familiares que eles respeitam do que aos de outros adultos randomicamente selecionados na sociedade;

que crianças e adultos experienciam emoções tais como orgulho ou vergonha quando estão aprendendo a respeito das experiências de outra pessoa ou grupo com que elas acreditam partilhar atributos;

que a intensidade dessas emoções vicárias está correlacionada com a distintividade das qualidades partilhadas. ... Esses três fatos convidam à especulação quanto ao processo psicológico responsável por esses fenômenos identificação é o termo usado mais freqüentemente para nomear esse processo (p.134).

A maioria das meninas de cinco anos, por exemplo, acredita que elas partilham mais aspectos com suas mães do que com seus pais. Em conseqüência, uma criança nessa idade que vê sua mãe assustada diante de uma tempestade pode inferir que o medo de tempestades também é uma de suas características. Por outro lado, uma garota que percebe sua mãe como corajosa, enérgica com seu pai e popular com as amigas será tentada a supor que também ela possui essas qualidades desejáveis.

Finalmente, o período histórico durante o qual viveram crianças e adolescentes pode ter uma profunda influência sobre os valores dos adultos. Kagan ilustra esse aspecto com o período de depressão econômica norteamericana, que durou de 1930 a 1940, e deixou cerca de um terço das famílias americanas cronicamente ansiosas quanto a sua segurança econômica. Nessa época, as crianças eram diariamente lembradas de que deveriam ser cuidadosas com as roupas, as mães economizavam nas refeições, enquanto os pais dirigiam carros velhos. As crianças de cinco anos talvez não estivessem amadurecidas o suficiente para sentir a ansiedade da família, mas os adolescentes, que eram sempre recordados da situação econômica que a família um dia teve, adquiriram uma preocupação com dinheiro que permaneceu por toda a vida. Uma grande proporção de americanos que eram adolescentes durante esses anos e estão agora com mais de setenta anos economizaram muito mais dinheiro do que as gerações antes ou após eles, e, durante toda a vida, manifestaram uma contínua preocupação com perdas financeiras. Em suma, conclui Kagan:

As conseqüências da ordem de nascimento, identificação com a classe social ou grupo étnico e do período histórico, cada um dos quais afeta o comportamento e as crenças de maneira profunda, têm pouca ou nenhuma relevância durante os primeiros dois anos de vida, mas cada um deles pode produzir nítidas descontinuidades no desenvolvimento e transformar as conexões entre a infância e a idade adulta ... Dessa forma, é adequado perguntar por que a idéia de determinismo infantil resiste tão bravamente às críticas (p. 146).

O próprio autor procura responder a essa questão apresentando uma série de razões para a vitalidade e permanência dessa crença na Psicologia.

Kagan acredita que a principal razão dessa resistência é que essa crença gera um sentimento de correção, ou de estar fazendo 
as coisas certas, derivado de nossos valores morais. A maioria dos americanos e europeus mantém a crença ética de que o cuidado materno é inerentemente melhor para as crianças do que os cuidados proporcionados por quaisquer outros adultos. A imagem de mães que entregam seus filhos aos cuidados de outras pessoas parece, para muitos, uma violação das leis naturais. Como resultado, quando os especialistas dizem que seria melhor se as mães se encarregassem do cuidado dos bebês, a maioria das pessoas tem a intuição de que eles estão falando a verdade. Quanto a isso, nós acrescentamos as suposições de conexões e de mudanças materiais no cérebro da criança causadas pela experiência, e é quase impossível resistir à conclusão de que o cuidado materno, nos primeiros anos, determina inexoravelmente o curso do desenvolvimento da criança para o bem ou para o mal.

Uma segunda razão porque tantas pessoas preferem acreditar no determinismo infantil é que ele ignora a importância de fazer parte de uma classe social. Ainda que, como centenas de estudos têm demonstrado, a classe social seja o melhor preditor da vocação futura, do desempenho escolar e de desordens psiquiátricas, gostamos de acreditar que nossa sociedade é aberta e igualitária, sem rígidos limites de classe social. Reconhecer o poder da pertinência a uma classe social é questionar essa crença ética.

Uma outra razão é a de que essa doutrina minimiza o papel do acaso, uma idéia que muitas pessoas acham desagradável, uma vez que reconhecer o seu papel é reconhecer que não temos condições de prever e controlar todas as coisas ao nosso redor.

A quarta razão para a vitalidade da idéia dessa crença é a de que o determinismo é materialista, isto é, ele supõe que as mudanças no cérebro criadas pelas primeiras experiências são permanentes, o que aparentemente simplifica muito a explicação do processo de desenvolvimento.

Ao término desse capítulo, Kagan deixa claro que não nega a influência dos eventos que ocorrem nos dois primeiros anos de vida, porém não atribui a eles um papel determinante no desenvolvimento da criança. Em suas palavras: "Os eventos dos primeiros anos colocam a criança num determinado caminho, mas um caminho com um número extraordinariamente grande de encruzilhadas" (p. 150).

\section{Comentários}

Como visto, Kagan apresenta muitas razões pelas quais o determinismo infantil é implausível. Falta, todavia, no meu entendimento, uma confrontação mais direta com estudos que procuram demonstrar o contrário, tais como os dos etólogos a respeito do bem comprovado fenômeno da estampagem (imprinting) em aves precociais e do não tão bem comprovado estabelecimento do vínculo entre mães e filhos nos primeiros meses de vida (apego), tal como proposto e bastante estudado por Bowlby (2002) e colaboradores.

Se, em relação ao primeiro tipo de estudo, podemos argumentar que se trata de espécies bastante diferentes, no tocante aos muitos estudos do apego em crianças, tal argumentação não se aplica. Ainda que a teoria do apego venha sendo bastante criticada em nossos dias (v., por ex., Lewis, 1999), acredito que ela ainda tenha um poder de sedução muito grande; daí a necessidade de uma discussão mais aprofundada dessa questão, analisando os estudos favoráveis e contrários a sua ocorrência, de modo a estabelecer claramente a existência ou não desse fenômeno tão inequivocamente ligado às primeiras experiências e de suas repercussões ao longo da vida da criança.

Um outro aspecto do determinismo infantil que chamou a atenção de Keil (1999) é o fato 
de que essa crença não está tão disseminada nem exibe tanta força quanto dá a entender o texto de Kagan. Certamente alguns pais se preocupam excessivamente com as conseqüências das primeiras experiências sobre o desenvolvimento dos filhos. No entanto, uma simples observação mostra claramente que a grande maioria dos pais não abandona suas crianças após os dois primeiros anos de vida como se tudo já estivesse determinado, restando a eles a tarefa de observar o desenvolvimento pré-estruturado das crianças. Como observa Keil (1999), o interesse dos pais no determinismo infantil é semelhante à aposta de Pascal sobre a existência de Deus. Ela parece implausível, mas as conseqüências de estar errado são tão terríveis que vale a pena ser cauteloso.

\section{O princípio do prazer}

Finalmente, no capítulo denominado $\mathrm{O}$ princípio do prazer, Kagan trata da terceira e última idéia sedutora. Essa idéia refere-se à crença bastante difundida e popular de que o comportamento humano é motivado primordialmente pela busca do prazer sensorial ou pela esquiva da dor.

Quando uma pessoa seleciona conscientemente uma ação ao invés de outra - por exemplo, ir a uma festa ou visitar um amigo no hospital - que objetivo ela busca? Duas respostas completamente diferentes podem ser dadas. Segundo alguns estudiosos, a pessoa busca, antes de tudo, obter um sentimento de prazer que se origina em uma ou mais das modalidades sensoriais.

O segundo tipo de resposta, qualitativamente diferente, tem sua origem no pensamento, e não na sensação. Nas palavras do autor:

O estado desejado é uma consonância conceitual entre uma idéia, denominada padrão, e a ação escolhida. Quando a consonância ocorre, a pessoa momentaneamente experiencia um sentimento agradável, porque seu comportamento está de acordo com um padrão que ela categorizou como bom... O estado criado pela excitação dos sentidos tem uma qualidade e duração que ninguém confundiria com aquele criado pelo reconhecimento de que uma ação, pensamento ou sentimento particular se emparelha a uma representação que a pessoa classificou como boa (p. 152).

A afirmativa de que o comportamento humano está a serviço de realçar um sentimento de virtude é apoiada pela observação corriqueira de que crianças e adultos gastam parte substancial de seu tempo pondo à prova sua competência. Crianças constroem castelos na areia e adultos escalam altíssimas e perigosas montanhas porque, segundo acredita o autor, esses tipos de ações são orientados por uma idéia de perfeição. Tal idéia constitui uma disposição tão biológica quanto a busca de sabores doces e a esquiva da dor corporal. Uma vez protegidos de danos físicos reais ou potenciais, a afirmação da virtude tem precedência sobre a busca do prazer sensorial na maior parte das vezes.

Embora o conteúdo de todo o conjunto de padrões morais esteja ligado a uma época e a um lugar, o desejo de acreditar que somos eticamente dignos é universal. Kagan ressalta que os seres humanos são a única espécie que aplica a avaliação simbólica de bom e mau, de certo e errado, a ações, pensamentos, sentimentos e características pessoais e tenta continuamente selecionar ações que levem os indivíduos a se verem como bons. Mais uma vez, o autor recorre ao testemunho de Darwin (1974), que afirmou claramente: "Eu subscrevo totalmente o julgamento daqueles autores que sustentam que, de todas as diferenças entre o homem e os animais inferiores, o senso ou consciência moral é, de longe, a mais importante" (p. 155). E conclui Kagan ousadamente: "Um motivo moral e
A afirmativa de

que o

comportamento humano está a serviço de realçar um sentimento de virtude é apoiada pela observação corriqueira de que crianças e adultos gastam parte substancial de seu tempo pondo à provasua competência. 
suas emoções concomitantes são um produto tão óbvio da evolução biológica quanto a digestão e a respiração" (p. 155).

O fato de toda sociedade ter um código moral indica que uma preocupação com o bem e o mal, o certo e o errado, seja uma característica biologicamente fundamentada. Obviamente, o conteúdo específico do código é influenciado por condições históricas, religiosas e econômicas. Embora algumas culturas proíbam comer carne de porco, enquanto outras proíbam o consumo de carne de vaca, todas as culturas têm tabus que, quando violados, tornam o agente menos virtuoso.

O autor nos previne de que seu propósito nesse capítulo não é prescritivo. Ele não está preocupado em defender intenções, emoções ou ações particulares como mais dignas do que outras. Meu intento, diz ele, “... é explorar a psicologia do agente humano e o desejo universal de considerar-se a si mesmo como bom e, como conseqüência, pensar e agir de modo a confirmar ao invés de negar essa avaliação" (p. 157).

Segundo descobertas da Psicologia do desenvolvimento, entre o segundo e o terceiro ano, a criança já tem condições de apreciar e usar as categorias de bom e mau, as quais, posteriormente, irá aplicar a suas ações, pensamentos e sentimentos. Qualquer informação que os seres humanos interpretem como indicação de que eles são bons ou maus tem uma conotação emocional. A ação em si é menos importante do que sua avaliação simbólica. Matar em legítima defesa é uma ação aceitável; a mesma ação cometida por um ladrão é condenável. De forma diferente de quaisquer outros animais, os seres humanos estão continuamente julgando as implicações morais de seus desejos e comportamentos.

Não obstante a importância de um motivo moral ter sido reconhecido por muitos filósofos e escritores, Kagan acredita que muitos cientistas sociais e biólogos não lhe têm atribuído a devida importância. Ele atribui esse relativo descaso para com o comportamento moral à penetrante influência da teoria da evolução. Segundo o autor, a maioria dos cientistas naturais acredita que

... não existe uma clara linha demarcatória entre animais e humanos e, em conseqüência, eles não estão dispostos a atribuir aos seres humanos quaisquer qualidades que os tornariam biologicamente distintos. À medida que as idéias de Darwin foram se tornando cada vez mais influentes durante a última década do século dezenove, os cientistas começaram a estudar os animais a fim de compreender a condição humana, na suposição de que nenhuma função psicológica humana apresentava uma séria descontinuidade com aquelas possuídas pelo menos por uma espécie animal (p. 159).

Todavia, como observa o autor, muitos cientistas a serviço da premissa da continuidade parecem não se sentir constrangidos por essa idéia, uma vez que escrevem sobre características ausentes nos animais, tais como raciocínio dedutivo, planejamento a longo prazo, desordens de aprendizagem, obsessão, esquizofrenia e anorexia.

O desenvolvimento de métodos poderosos para investigar as conseqüências ou os derivativos dos genes e a melhor compreensão da fisiologia cerebral de animais encorajaram os biólogos a insistir na validade da premissa da continuidade implícita na teoria de Darwin. Uma vez que os rigorosos padrões positivistas das disciplinas biológicas exigem um elevado grau de controle experimental, que só pode ser satisfeito no estudo com animais, as investigações de processos tais como o medo, a percepção, a memória e o condicionamento, que podem ser adequadamente estudados em animais, tiveram precedência sobre o estudo de motivos e emoções morais, que não têm análogos óbvios nesse tipo de criatura. 
Porém, palavras como cooperar, comunicar, roubar, matar, trapacear, egoísmo, lealdade e honestidade foram inventadas há milênios para descrever o comportamento humano. O sentido e o significado referencial desses termos são apropriados apenas para seres humanos. O fato de que dois macacos se comportem como se fossem cooperativos, simplesmente porque ambos os animais se beneficiam da cooperação, tem interesse científico e convida ao estudo e à explicação. Não é claro, no entanto, que esse comportamento possua os atributos definidores do que se entende por cooperação humana, ou seja, a consciência simultânea dos agentes tanto da necessidade do outro quanto da sua capacidade e obrigação de auxiliar. Uma abelha não está sendo "cooperativa" com uma planta quando ela carrega o pólen dessa planta para outra flor. Como salienta Kagan:

Uma similaridade única, objetiva, entre o comportamento cooperativo, agressivo ou egoísta de seres humanos e uma ação em outra espécie de animal é extremamente fácil de identificar. Mas, se os fundamentos psicológicos dos comportamentos animais e humanos são diferentes, nós deveríamos refletir cuidadosamente antes de utilizar a mesma palavra (p. 162).

Com essa observação, o autor encaminha seus argumentos no sentido de defender a existência de traços singularmente humanos, qualitativamente diferentes dos de outras espécies, não obstante a ocorrência de similaridades superficiais. Segundo ele:

Ratos, gatos, macacos e humanos compartilham muitas estruturas e funções importantes que implicam considerável continuidade na evolução, mas esse fato não significa que algumas espécies não possam possuir uma ou mais funções qualitativamente distintas que não partilham aspectos óbvios com seus parentes filogenéticos (p. 163). Ou ainda: um motivo moral, que representa uma nítida ruptura com nosso passado filogenético, não é simplesmente uma versão complexa de abelhas operárias que ajudam na sobrevivência da colméia ou um chimpanzé que permanece quieto, cabeça abaixada, diante de um membro morto de seu grupo. A relutância em reconhecer a singularidade do motivo moral humano é um tanto estranha, visto que os biólogos reconhecem traços únicos num grande números de espécies. O traçado de teias pelas aranhas, a ecolocalização nos morcegos e a estampagem em pássaros precociais são restritos a um gênero ou espécie particular. Características singulares são totalmente consistentes com a teoria de Darwin (p. 164). ... Eu não sugiro que a pesquisa com animais não tenha valor ... Animais e seres humanos compartilham muitos aspectos. Mas eles não compartilham todos eles. Os domínios com o mínimo de aspectos comuns envolvem intenções, valores e comportamentos associados com ansiedade, vergonha, culpa e orgulho. A evidência obtida com animais traz poucas contribuições para compreender esses estados humanos (p. 166).

Admitida a existência dessa capacidade singular - o senso moral - na espécie humana, Kagan se pergunta como ela emerge no decorrer do desenvolvimento, e ele mesmo propõe uma resposta:

A capacidade humana de um senso moral e de suas emoções correlatas tomou de nossa ancestralidade primitiva uma refinada sensibilidade à voz, ao rosto e às ações de outras pessoas e acrescentou cinco capacidades singulares : 1) inferir os pensamentos e sentimentos dos outros, 2) ser autoconsciente, 3) atribuir categorias de bom e mau a eventos e a si mesmo,4) refletir sobre ações passadas e 5) saber que uma ação particular poderia ter sido suprimida. A combinação desses cinco talentos criou um novo sistema que começa a emergir nas crianças no segundo ano e amadurece durante a década que se segue (p. 169). 
Segundo o autor, os primeiros sinais de competência moral podem ser observados em todos os lares. Uma criança de dois anos olha para os pais depois de derrubar água ou suco no tapete. O rosto e a postura da criança parecem indicar que ela sabe que cometeu um ato que viola aquilo que ela sabe que é certo. Por outro lado, a criança de um ano que despeja água no assoalho não mostra esses sinais de antecipação da desaprovação paterna, ainda que seus pais a tenham repreendido por essa ação. A criança de um ano tem muitas oportunidades de aprender que atos que destroem a integridade da propriedade são inaceitáveis, mas suas capacidades cognitivas não estão amadurecidas o suficiente para associar o significado simbólico de sua ação com a desaprovação dos adultos. Segundo Kagan, alguma coisa acontece na mente da criança durante o segundo ano de vida que a deixa sensível à adequação ou propriedade de seu comportamento.

A partir daí, a criança começa a criar categorias de "bom" e "mau" e a atribuí-las às coisas do mundo. Os referentes ao conceito de mau constituem famílias de eventos cujos aspectos principais são o sentimento de incerteza da criança diante da desaprovação do adulto, dor física, perda de algum objeto ou de alguma pessoa à qual a criança está apegada, frustração e antecipação de dano. Similarmente, uma família de sentimentos representa a categoria complementar de "bom". Eles incluem eventos que geram sensações agradáveis de gosto, toque e aroma, orgulho dos adultos, objetos e pessoas aos quais a criança está apegada e aquisição de um objetivo após um esforço e assimilação de um evento discrepante.

A maioria das crianças de dois anos está consciente do fato de que elas são indivíduos com características, sentimentos e intenções particulares. Quando esse aspecto da autoconsciência aparece, as crianças aplicam os rótulos de bom e mau a si mesmas, do mesmo modo que elas já vinham fazendo com pessoas, eventos e comportamentos nos últimos meses. Segundo Kagan, nesse insight reside a origem do motivo moral. O desejo de evitar ser rotulado como mau aumenta à medida que a criança amadurece e, gradualmente, vai adquirindo precedência sobre o medo da desaprovação e punição, vindo a tornar-se o principal governante do comportamento humano.

A seguir, e até o final do capítulo, Kagan critica veementemente a prática corriqueira em nossos dias de buscar, na história evolutiva do ser humano, as justificativas para os comportamentos moralmente condenáveis. Em suas próprias palavras:

É um erro supor que toda ética humana seja claramente derivada de alguma classe de comportamento animal...A preocupação com o certo e o errado, o controle da culpa e o desejo de sentir-se virtuoso é, da mesma maneira que o aparecimento do leite em mamíferos, um evento único que não apresenta continuidade com o que veio antes... O desejo contínuo de considerar-se a si mesmo como bom é um aspecto singular do Homo sapiens (p. 190)... Nosso senso moral não é uma fina camada que cobre uma constituição bestial e egoísta, mas um aspecto necessário a uma espécie com um lobo frontal tão grande que permite à pessoa ancorar ressentimentos, inveja, ciúme e hostilidade por um longo tempo depois que a raiva se dissipou... O senso moral, como a teia da aranha, é um produto único da evolução que se manteve porque ele assegura nossa sobrevivência (pp. 192/3).

E, com essas observações, Jerome Kagan encerra os capítulos nos quais tratou de idéias tão influentes quanto falaciosas da Psicologia contemporânea. No curto epílogo com o qual termina o livro, ele nos propõe quatro sugestões construtivas, que decorrem das 
considerações/discussões apresentadas no decorrer de seu trabalho.

\section{Comentários}

Ao criticar esta que, a meu ver, é a mais controvertida das idéias sedutoras, Kagan demonstra preocupação com o fato de a moralidade ser vista, com demasiada freqüência, como originária da simples busca do prazer e esquiva da dor. Essa discussão é a culminação de um tema que atravessa todo o livro, qual seja, a de que os seres humanos são singularmente diferentes de todos os outros animais. Kagan acredita que a moralidade deriva da capacidade humana de pensar simbolicamente, o que propicia o desenvolvimento, ao longo dos anos, de crenças e valores a respeito do que é bom e mau, certo e errado.

Mas, podemos questionar, até que ponto é possível considerar nossas ações orientadas por nossas crenças e valores, ao invés de por outros fatores dos quais não temos consciência? Ou, como indaga Keil: "As pessoas geralmente chegam a uma decisão bem pensada, e então agem, ou elas agem primeiro, e então buscam justificar suas ações?" (p. 549). Essa citação nos alerta para a necessidade de não considerarmos a capacidade singularmente humana de pensar a respeito de questões morais como evidência de que tais pensamentos são, necessariamente, os fundamentos de nossas ações. Muito embora cada um de nós acredite (ou prefira pensar) que agimos de acordo com elevados princípios morais, estudos de Psicologia social e, particularmente, a psicanálise e seu conceito de inconsciente desafiam essa crença. $\mathrm{Na}$ verdade, não é incomum, mormente em contextos clínicos, depararmo-nos com comportamentos que, sob o disfarce de princípios morais, revelam a atuação de motivos menos nobres.
Ainda que a história da humanidade e as histórias pessoais de milhões de pessoas estejam repletas de exemplos em que o prazer é substituído pelo dever, a satisfação pela obrigação, indicando claramente que o ser humano é perfeitamente capaz de orientar suas ações por valores e crenças a respeito do que acredita ser bom, certo, correto e virtuoso, e de evitar o que considera mau, errado, incorreto e vicioso, a pergunta que se impõe à Psicologia é: "Quão comuns são esses casos?"

\section{Quatro sugestões preciosas}

A primeira sugestão, que ele resume na seguinte frase: sentenças completas, por favor! - requer uma moratória no uso de termos imprecisos como medo, aprendizagem, ansiedade, inteligência, agressividade, altruísmo, etc, para os quais a situação de observação não é especificada e o agente tanto pode ser um rato, um pombo, um macaco ou um estudante universitário. Kagan salienta que o imperativo de especificar o agente e a situação deve ser considerado especialmente por aqueles que argumentam que as qualidades adultas são produtos das primeiras experiências. A não ser que os cientistas estabeleçam, em maiores detalhes, a forma específica de associação entre o passado e o presente, é razoável questionar essa afirmativa geral de que os primeiros eventos determinam necessariamente alguma conseqüência futura. Quando os psicólogos que estudam a memória distinguiram entre os processos de memória declarativa, episódica, implícita e de procedimentos, esse fenômeno psicológico pode ser muito melhor compreendido. É muito provável que surpreendentes progressos sejam realizados adotando-se uma estratégia analítica semelhante para muitos conceitos das ciências humanas e sociais.

A segunda sugestão exige: uma diversidade de procedimentos. Os cientistas sociais e
"As pessoas geralmente chegam a uma decisão bem pensada, e então agem, ou elas agem primeiro, e então buscam justificar suas ações?"

Keil 
comportamentais apóiam-se em três formas de informação para elaborar seus conceitos:

- afirmações verbais, incluindo auto-relatos e descrições de informantes;

comportamentos observados, tanto no laboratório quanto em situações naturais e

- medidas fisiológicas. Cada uma dessas fontes leva a conclusões diferentes. As descrições de uma pessoa baseadas unicamente na informação verbal - fornecida por si mesma ou pelos outros - podem ser coerentes, mas serão diferentes das descrições baseadas na pessoa observada ou nas informações fisiológicas a seu respeito. Nas palavras do autor:

Quando nós nos limitamos a uma fonte de informação, pagamos o preço da compreensão limitada (...) Não deveria ser uma fonte de orgulho que cientistas sociais prefiram descrições verbais de uma pessoa a avaliações diretas da ação, do ânimo e da fisiologia? Essa estratégia não reflete uma diferença epistemológica entre as ciências sociais, de um lado, e a Biologia e a Química, do outro. Ao invés disto, ela reflete uma falha em perceber que uma compreensão profunda não é possível com apenas uma fonte de informação. O progresso pode ocorrer apenas quando variadas fontes de evidência são combinadas (p. 197) (...) Eu suspeito que a adição de evidência biológica à informação psicológica criará novos e frutíferos conceitos, substituindo noções originadas na fenomenologia por construtos teoricamente mais úteis e mais fiéis à natureza (p. 198).

A terceira máxima sugere: considere as categorias. Com essa sugestão, o autor assinala que, ao invés de considerar todas as diferenças individuais meramente variações quantitativas ao longo de um contínuo, nós deveríamos considerar a utilidade potencial de criar categorias qualitativas que representem indivíduos nos extremos de uma dimensão ou que agrupem indivíduos que possuem uma combinação particular de traços. Adultos extremamente sociáveis, por exemplo, são qualitativamente, não apenas quantitativamente, diferentes daqueles que são apenas moderadamente sociáveis.

A última sugestão - leve em conta a mente recomenda àqueles que estudam os seres humanos que não deixem de perguntar como as pessoas interpretam a experiência. A opinião de Kagan é que a maioria dos cientistas sociais estuda a influência de eventos que podem ser facilmente quantificáveis violência na televisão, punição paterna ou número de divórcios - porque eles não possuem métodos que permitam um insight sobre as construções mentais privadas de adultos e crianças. Ele, então, sugere que: “Nós devemos inventar métodos novos a fim de descobrir o grande número de associações tácitas, porém informativas, que as pessoas possuem, especialmente aquelas que são derivadas de identificações com o gênero, a família, a classe social e os grupos étnicos (p. 199)".

Essa sugestão de levar em conta os eventos internos é feita, segundo o autor, dentre outras razões, porque é sabido que, na maior parte do tempo, as mentes são despertadas pela discrepância ou pela diferença relativa, ao invés de por um evento específico definido de forma absoluta. Assim, para ilustrar com um exemplo, o aparecimento de uma rosa numa tela produz uma onda cerebral específica apenas quando ela é precedida por muitas figuras de outros objetos que não são rosas e, em conseqüência, há uma discrepância. Um estado de surpresa automaticamente provoca uma tentativa de interpretação que é a governante crítica do comportamento. Kagan afirma que não é a timidez que torna alguns psicólogos relutantes em orientar os pais como se comportar com os filhos, mas a percepção de que não é qualquer ação paterna específica, mas a interpretação da criança que modela o seu desenvolvimento. Bater numa criança por um 
comportamento inadequado poderá ter conseqüências maléficas ou não. Tudo irá depender da maneira pela qual a criança interpreta a punição: como algo justo ou injusto. Com essas palavras, Jerome Kagan finaliza seu instigante livro (p.199):

Os seres humanos interpretam a mudança de maneira complexa, simbólica - o animais não o fazem - e uma das primeiras interpretações impostas sobre a experiência é se a mudança é boa ou má, para nós mesmos e para aqueles de quem cuidamos. Nenhum animal faz esse cálculo.

\section{Considerações finais}

Não obstante as limitações apontadas, acredito que tenha valido a pena o esforço de ter procurado divulgar as idéias de Kagan para a comunidade psicológica brasileira. Ainda que tais idéias possam ser menos prevalentes entre os psicólogos do que supõe este autor, certamente existem alguns nichos teóricos que partilham e divulgam tais crenças com muita ênfase e dogmatismo. Penso que a psicanálise e a análise experimental do comportamento possam ser citadas como exemplos. Assim sendo, uma palavra de precaução para os que já adentraram ou irão adentrar em tais nichos poderá despertar um saudável sentimento de ceticismo a respeito dessas idéias e levar a uma avaliação (ou reavaliação) mais cuidadosa de sua veracidade.

Um aspecto que decorre das críticas de Kagan a essas idéias sedutoras é uma visão mais enobrecedora do homem. Ao realçar que as diferenças entre homens e animais não são apenas de natureza quantitativa, mas, sobretudo, qualitativa, que o ser humano tem uma notável capacidade de resiliência e de mudança durante toda a sua vida, que não é um mero joguete de forças ambientais, mas que pode ser dirigido por princípios e ideais, que as capacidades cognitivas são absolutamente essenciais para a compreensão de vários aspectos de seu desenvolvimento, o autor nos apresenta um quadro mais reconfortante da natureza humana. Se esse quadro corresponde ou não à realidade dos fatos é, e, no meu entendimento, continuará sendo ainda por muitos anos, uma questão de disputa entre os psicólogos. Todavia, ao ressaltar os aspectos distintivamente humanos e ao fazer uma crítica de algumas idéias longamente acalentadas pela Psicologia, Kagan contribui decisivamente para suscitar debates sobre sua veracidade.

No início de sua resenha, Keil (1999) afirma que não basta apenas descrever e criticar tais idéias. Tão importante quanto descrevê-las é procurar entender por que essas idéias sedutoras ainda persistem na Psicologia e por que elas são tão resistentes à extinção.

Sem pretender esgotar a questão proposta por Keil, penso que pelo menos uma parte da resposta pode ser encontrada no fato de que tais crenças refletem, em grande parte, a maneira de pensar dos cientistas naturais, pois, ao questionar tais idéias, o autor implicitamente está dirigindo suas críticas a três características fundamentais da ciência clássica, quais sejam, o essencialismo, o determinismo e o utilitarismo.

O essencialismo está bem refletido na crença de que os processos psicológicos podem ser amplamente generalizados, uma vez que as diferenças que apresentam são meramente superficiais e/ou acidentais. Uma análise mais profunda, tal como a realizada pela ciência, certamente descobrirá aspectos comuns ou essenciais, partilhados por todos os membros de uma classe ou categoria, subjacentes aos aspectos superficiais ou não essenciais. E são essas características ou aspectos essenciais que permitem e justificam as amplas generalizações feitas na Psicologia.

O determinismo está claramente presente na crença de que as primeiras experiências têm 
um poder determinante sobre a vida futura de uma criança. O próprio Kagan destaca a atração exercida por essa idéia ao ressaltar que ela nos dá a ilusão de estabelecer uma clara relação de causa e efeito entre as experiências anteriores e as conseqüências posteriores. Não é preciso insistir que essa idéia mecanicista é uma das mais caras à ciência tal como comumente a concebemos.

Finalmente, o utilitarismo está bem refletido na idéia de que a moral humana reduz-se simplesmente à busca do prazer e à fuga da dor. Como se sabe, o utilitarismo é um tipo de ética normativa - originada da obra dos filósofos e economistas ingleses Jeremy Bentham e John Stuart Mill - segundo a qual uma ação é moralmente correta se tende a promover a felicidade e condenável se tende a produzir a infelicidade. Bentham, que aparentemente acreditava que o indivíduo, em seu comportamento, iria sempre buscar maximizar seu prazer e minimizar seu sofrimento, coloca no prazer e na dor a causa das ações humanas e as bases de um critério normativo da ação (Cobra, 2001), ignorando, segundo Kagan (1998), a distinção entre o prazer dos sentidos e o prazer da virtude, uma vez que este último resiste à quantificação. Assim, essa idéia parece ajustar-se melhor aos preceitos da ciência clássica, tanto pela possibilidade de mensurar os fenômenos quanto pela sedutora (mas, equivocada) possibilidade de retraçar o desenvolvimento do comportamento a suas origens.

Em suma, poder-se-ia hipotetizar que a Psicologia assimilou tão facilmente essas idéias, na ânsia de ser considerada uma ciência respeitável, que daí decorre a dificuldade de abrir mão delas em prol de novas formas de pensar o comportamento humano. De modo interessante, parecemos estar voltando à velha discussão, que muitos consideram há muito superada, sobre o status da Psicologia como ciência. Talvez tenhamos ainda de refletir um pouco mais sobre a questão. Se esse for o caso, acredito que as idéias de Kagan, expostas em Three Seductive Ideas, possam enriquecer bastante a discussão. 
José Fernando Bitencourt Lomônaco

Universidade de São Paulo - Academia Paulista De Psicologia Rua Matheus Grou, 79, ap. 62, CEP 05415-050, São Paulo. Fone (11) 3064-7156 (res) e (11) 3091-4185 r. 223. E-mail: jfblusp@usp.br e jfblusp@terra.com.br

Recebido 12/05/05 Reformulado 05/06/06 Aprovado 12/06/06

BOWLBY, J. Apego. 3. ed. São Paulo: Martins Fontes, 2002.

COSTA, R. B. Temas da Filosofia. Site. www.cobra.pages.nom.br. Brasília, 2001.

KAGAN, J. Three Seductive Ideas. Massachusetts: Harvard University Press, 1998.
KEIL, F. C. Developmental Psychology. In: Contemporary Psychology, v. 44, no. 6, pp. 547-548, 1999.

LEWIS, M. Alterando o Destino: porque o Passado não Prevê o Futuro. Campinas: Editora UNICAMP/Editora Moderna, 1999.
Referências 